\title{
Limited TeNDERING - A BARRIER TO GET \\ THE BEST VALUE FOR MONEY OR EFFECTIVE SOLUTION FOR EXTRAORDINARY SituATIONS?
}

\section{Hana Kováčiková \& Ondrej Blažo}

\author{
Comenius University in Bratislava, Slovakia
}

\section{hana.kovacikova@flaw.uniba.sk, ondrej.blazo@flaw.uniba.sk}

KOVÁČIKOVÁ, Hana; BLAŽO, Ondrej. Limited Tendering - A Barrier to Get the Best Value for Money or Effective Solution for Extraordinary Situations?. International and Comparative Law Review, 2020, vol. 20, no. 2, pp. 192-214. DOI: $10.2478 /$ iclr-2020-0024

\begin{abstract}
Summary: A public procurement should be an effective tool through which public authorities shall spend public finances sparingly. With modernisation of this area of law in 2014, a new concept of bids evaluation came forward - a value for money. Now it is more important than any time before to ensure fair tenders to be submitted during the procurement. It is a well-known fact, that only a true competition between the bidders decreases the prices and raises the quality of their bids. But how contracting authorities deal with these goals while procuring without competition? This article analyses limited tendering with focus on extreme urgency. Authors try to give an answer to the question, which attribute of this procedure prevails - its flexible use in extraordinary situations or its interfering effect to value for money achievement.which makes Slovakia open to severe criticism from international human rights bodies.
\end{abstract}

Keywords: public procurement, best value for money, competition, limited tendering.

\section{Introduction}

EU public procurement regulation is designed to achieve a competitive, open, and well-regulated procurement market, where the buyer can procure goods, services or works in best value for money. To agree with Glendinning, ${ }^{1}$ concept of best value for money should be understood as not paying more for a good or service than its quality or availability justify. In relation to public spending, it implies a concern with economy (cost minimisation), efficiency (output maximisation) and effectiveness (full attainment of the intended results) and relates to whole-life cycle of the procured items. The Public Procurement Directive ${ }^{2}$ later explains in its Recital, that the best value for money concept also considers

1 GLENDINNING, R. The Concept of Value for Money. International Journal of Public Sector Management, 1988, vol. 1, no. 1, pp. 42-50, ISSN: 095-3558

2 Directive 2014/24/EU of the European Parliament and of the Council of 26 February 2014 on public procurement and repealing Directive 2004/18/EC, point 93 
conditions of delivery and payment, aspects of after-sale service or environmental or social aspects.

A best value for money can be achieved, if tenderers really compete during bidding. A true competition between tenderers is therefore an essential prerequisite to this goal. However, Union' $\mathrm{s}^{3}$ and even global ${ }^{4}$ public procurement regulation allows methods of procurement with limited or even excluded competition (negotiated procedure without prior call for publication / direct award). Reasons for derogation from competitive procedures are similar (see Table 1 below) and vary from the absence of competitors, through exclusive rights, emergency situations, commodity market purchases to exceptionally advantageous conditions and some others. It has to be noted, that only situations of objective exclusivity can justify the use of uncompetitive procedure, where the situation of exclusivity has not been created by the contracting authority itself with a view to the future procurement procedure. Moreover, contracting authorities relying on this exception should provide reasons why there are no reasonable alternatives or substitutes such as using alternative distribution channels including outside the Member State of the contracting authority or considering functionally comparable works, supplies and services.

\section{Table 1: Comparison of EU/WTO reasons for limited tendering}

\begin{tabular}{|c|c|}
\hline Directive 2014/24 (Article 32) & GPA 2012 (Article XIII) \\
\hline $\begin{array}{l}\text { where no tenders or no suitable tenders } \\
\text { or no requests to participate or no suit- } \\
\text { able requests to participate have been } \\
\text { submitted in response to an open proce- } \\
\text { dure or a restricted procedure, provided } \\
\text { that the initial conditions of the contract } \\
\text { are not substantially altered and that a } \\
\text { report is sent to the Commission where } \\
\text { it so requests. }\end{array}$ & $\begin{array}{l}\text { where no tenders were submitted or no sup- } \\
\text { pliers requested participation; no tenders } \\
\text { that conform to the essential requirements } \\
\text { of the tender documentation were submit- } \\
\text { ted; no suppliers satisfied the conditions for } \\
\text { participation; or the tenders submitted have } \\
\text { been collusive }\end{array}$ \\
\hline $\begin{array}{l}\text { where the products involved are man- } \\
\text { ufactured purely for the purpose of } \\
\text { research, experimentation, study } \\
\text { or development; however, contracts } \\
\text { awarded pursuant to this point shall not } \\
\text { include quantity production to estab- } \\
\text { lish commercial viability or to recover } \\
\text { research and development costs; }\end{array}$ & $\begin{array}{l}\text { where a procuring entity procures a proto- } \\
\text { type or a first good or service that is devel- } \\
\text { oped at its request in the course of, and for, } \\
\text { a particular contract for research, experi- } \\
\text { ment, study or original development. }\end{array}$ \\
\hline
\end{tabular}

3 See the Article 32 of the Public Procurement Directive (2014/24/EU) and Article 50 of the Utilities Directive (2014/25/EU).

4 To this regard see Article XIII WTO's Revised Government Procurement Agreement (2012) 
where the works, supplies or services can be supplied only by a particular economic operator for any of the following reasons: (i) the aim of the procurement is the creation or acquisition of a unique work of art or artistic performance; (ii) competition is absent for technical reasons; (iii) the protection of exclusive rights, including intellectual property rights;

in so far as is strictly necessary where, for reasons of extreme urgency brought about by events unforeseeable by the contracting authority, the time limits for the open or restricted procedures or competitive procedures with negotiation cannot be complied with.

for additional deliveries by the original supplier which are intended either as a partial replacement of supplies or installations or as the extension of existing supplies or installations where a change of supplier would oblige the contracting authority to acquire supplies having different technical characteristics which would result in incompatibility or disproportionate technical difficulties in operation and maintenance; the duration of such contracts as well as that of recurrent contracts shall not, as a general rule, exceed three years;

for new works or services consisting in the repetition of similar works or services entrusted to the economic operator to which the same contracting authorities awarded an original contract, provided that such works or services are in conformity with a basic project for which the original contract was awarded pursuant to a procedure in accordance with Article 26(1).

for supplies quoted and purchased on a commodity market;

for the purchase of supplies or services on particularly advantageous terms, from either a supplier which is definitively winding up its business activities, or the liquidator in an insolvency procedure, an arrangement with creditors, or a similar procedure under national laws or regulations. where the goods or services can be supplied only by a particular supplier and no reasonable alternative or substitute goods or services exist for any of the following reasons: (i) the requirement is for a work of art; (ii) the protection of patents, copyrights or other exclusive rights; or (iii) due to an absence of competition for technical reasons;

insofar as is strictly necessary where, for reasons of extreme urgency brought about by events unforeseeable by the procuring entity, the goods or services could not be obtained in time using open tendering or selective tendering;

for additional deliveries by the original supplier of goods or services that were not included in the initial procurement where a change of supplier for such additional goods or services: i. cannot be made for economic or technical reasons such as requirements of interchangeability or interoperability with existing equipment, software, services or installations procured under the initial procurement; and ii. would cause significant inconvenience or substantial duplication of costs for the procuring entity;

\section{ket;}

for purchases made under exceptionally advantageous conditions that only arise in the very short term in the case of unusual disposals such as those arising from liquidation, receivership or bankruptcy, but not for routine purchases from regular suppliers; 
where the public service contract con- where a contract is awarded to a winner of cerned follows a design contest organ- a design contest provided that: the contest ised in accordance with this Directive has been organized in a manner that is conand is to be awarded, under the rules sistent with the principles of this Agreement, provided for in the design contest, to in particular relating to the publication of the winner or one of the winners of the a notice of intended procurement; and the design contest; in the latter case, all win- participants are judged by an independent ners must be invited to participate in the jury with a view to a design contract being negotiations. awarded to a winner.

As the Court of Justice of the European Union (hereinafter only "CJEU")

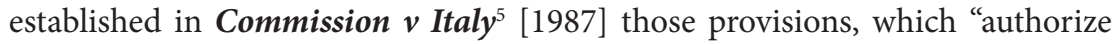
derogations from the rules intended to ensure the effectiveness of the rights conferred by the Treaty in the field of public works contracts, must be interpreted strictly and the burden of proving the actual existence of exceptional circumstances justifying a derogation lies on the person seeking to rely on those circumstances."

Furthermore, in Fastweb ${ }^{6}$ [2014], the CJEU reminded that the negotiated procedure "may only be used in the circumstances precisely delimited in [now Article 32 of Directive 2014/24] and that, as compared with open and restricted procedures, that procedure is exceptional." Said in other words, any other exemptions from the general rules, even these uncompetitive methods must be exceptional, well-reasoned and not leading to abuse the rules. Contracting authority shall justify clearly and unequivocally the reasons that moved it to consider it legitimate to award the contract without prior publication of a contract notice, so that interested persons are able to decide with full knowledge of the relevant facts whether they consider it appropriate to bring an action before the review body and so that review body is able to undertake an effective review.

This approach was later confirmed also in CJEU's decisions Commission v Greece $^{7}$ [2005] or Commission $\boldsymbol{v}$ Greece $^{8}$ [2009] and finally in Recital 50 of the Public Procurement Directive [2014]: "Contracting authorities relying on this exception should provide reasons why there are no reasonable alternatives or substitutes such as using alternative distribution channels including outside the Member State of the contracting authority or considering functionally comparable works, supplies and services."

At the same time, it is not possible to introduce additional grounds into the legal systems of member states which in practice would extend the scope of

5 Case 199/85, para.14

6 Case C-19/13, paras. 48,49

7 Case C-394/02, para. 33

8 Case C-250/07, para. 17 
application of the negotiated procedure without publication of a contract notice. ${ }^{9}$ Limits for the use of limited tendering methods therefore seems to be clear.

To this regard, a Graph 1 below proves, that direct awards of the contract through the negotiated procurement procedure on the national level, after implementation of Public Procurement Directive [2014], ${ }^{10}$ is in more than a half of the Member States, lower than 5\% of all bids. However, it seems that in Romania, Slovenia, Cyprus, and Bulgaria direct awarding of contracts without competition still remains an actual problem.

Graph 1: Negotiated procurement procedures without calls for bids

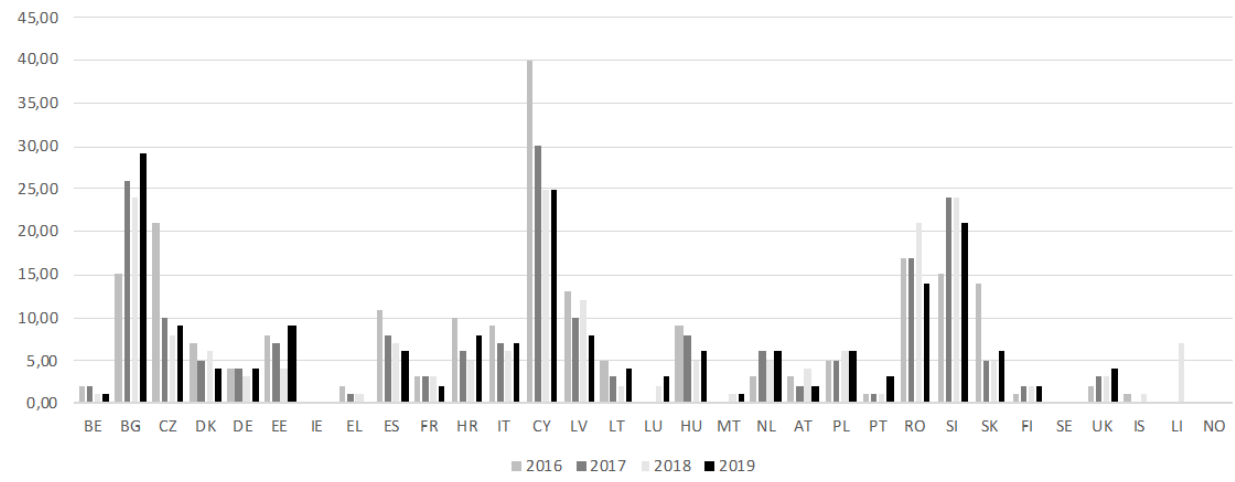

Source: European Commission ${ }^{11}$

With the aim to verify this trend even in public procurements at the Union's level (i. e. where the EU thresholds are met), authors had analysed data from TED database ${ }^{12}$ relating to contract award notices within the period from 1 January 2016 to 31 December 2019. While in 2016 awarded contracts through the negotiated procedure without a call for competition represented 5,13\% of all awarded contracts ${ }^{13}$, in 2017 this share decreased to $5,07 \%{ }^{14}$, in 2018 to

9 HORUBSKI, Krzysztof. Public Contracts by Negotiated Procedure in Cases of Urgency - A New interpretation of the Legal Basis in Light of Experiences with Organization of the 2012 European Football Championships - Wroclaw Review of Law, Administration \& Economics, 2014, vol. 3, no. 1, p. 106, DOI: https://doi.org/10.2478/wrlae-2013-0046 ISSN: 2084-1264. [online] Available at: https://content.sciendo.com/configurable/contentpage/ journals $\$ 002$ fwrlae $\$ 002 \mathrm{f} 3 \$ 002 \mathrm{f} 1 \$ 002$ farticle-p104.xml Accessed: 10.12 .2020

10 Member States were obliged to comply with this directive by 18 April 2016.

11 EUROPEAN COMMISSION. Internal Market. [online] Available at: https://ec.europa.eu/ internal_market/scoreboard/performance_per_policy_area/public_procurement/index_ en.htm Accessed: 15.11.2020

12 Available at: https://ted.europa.eu/TED/search/search.do (visited on 20 November 2020)

13 From 178053 award contract notices (services: 89 895, supplies: 61 290, works: 26 868), 9140 (services: 4 511, supplies: 4 511, works:560) referred to negotiated procedure without a call for competition.

14 From 204847 award contract notices (services: 100 778, supplies: 74 097, works: 29 972)

Published by Palacký University Olomouc, Czech Republic, 2020.

ISSN (print): 1213-8770; ISSN (online): 2464-6601 
$4,58 \%{ }^{15}$ and finally to $4,46 \%{ }^{16}$ of all awarded contracts in 2019. (see Graph 2 below)

Graph 2: Overview of all awarded contacts / contract awards through negotiated procedure without a call for competition

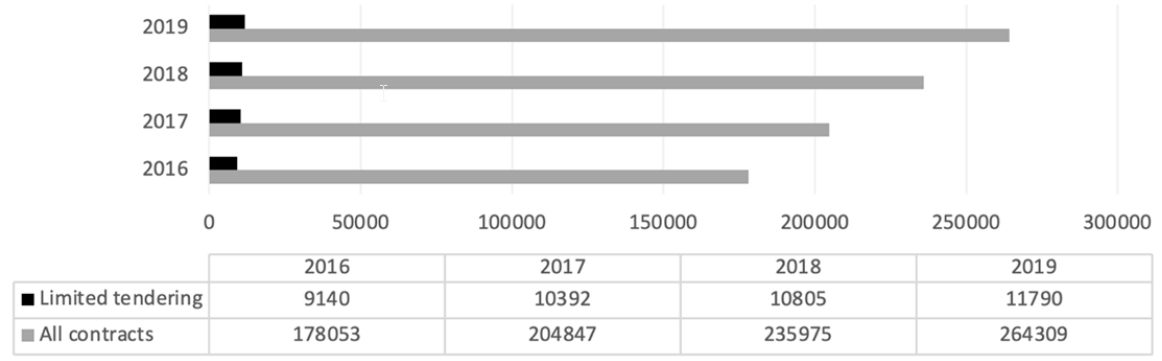

Source: authors, TED database (all data in this paper are valid on 6 December 2020)

To sum up this part, public procurement at Union's level through negotiated procedure without a prior notification follows the trend of decrease occurred in most of the Member States. And that is a good sign. Decrease of the share of limited tendering in public procurement leads to increase of competitive procuring methods.

General conclusion to this regard therefore might be, that Union's regulation really helps to meet set goals - achieve a competitive, open and well regulated procurement market, where contracting authority can procure goods, services and works in best value for money.

However, when analysing other aspects of direct awarding of contracts, author focused on question how the distribution of contract awards affects the market structure.

\section{Distribution of contract awards and impact of limited tendering thereon}

As said earlier, aims of the directives on public procurement shall be recalled in the context 0of limited tendering, in particular their essential goal - openness of national markets on internal market and free flow of goods, services, capital,

10392 (services: 4979, supplies: 4 873, works: 540) referred to negotiated procedure without a call for competition.

15 From 235975 award contract notices (services: 116 809, supplies: 85 836, works: 33 330) 10805 (services: 5345, supplies: 4 960, works: 500) referred to negotiated procedure without a call for competition.

16 From 264309 award contract notices (services: 129 062, supplies: 96 781, works: 38 466) 11790 (services: 6010, supplies: 5 152, works: 628) referred to negotiated procedure without a call for competition. 
payments as well as securing freedom of establishment. ${ }^{17}$ Along the other goals, the EU system of public procurement shall contribute to sustainable growth involving an enabling participation of small and medium enterprises (SMEs). ${ }^{18}$ While in the case of public procurement procedures with prior publication of call, the structure of suppliers, or should be, generated by market itself, in the case of limited tendering, the structure of suppliers, i.e. cross-border supplies or supplies by SMEs, depends purely on discretion of the contracting authority.

Possible change of patterns of "public procurement market" will go under the scrutiny of the following quantitative analysis of contract awards. The CVS datasets of the TED ${ }^{19}$ provide source of information for analysis, although authors are being aware of possible errors and shortcoming of these databases provided by the European Commission. ${ }^{20}$

The distribution of contracts ${ }^{21}$ was analysed on the basis of two criteria: on the basis of number of awards and on the basis of the value of the contracts. ${ }^{22}$

It is apparent that the majority of winners of bids are established in the country of contracting authority (CA) (Table 2) and this outcome does not differ in the analysis based on the number of awarded contracts. Indeed, subsidiary of parent company that is established in the country of contracting authority is considered still domestic economic operator, notwithstanding country of establishment of the parent company. In many instances, there occurs presence of economic operators from neighbouring countries or countries with the same or similar official language, e.g. German companies in Austria and vice versa, British companies in Ireland and vice versa, Czech companies in Slovakia and vice versa.

17 Recital 1 of the Public Procurement Directive.

18 Recital 2 of the Public Procurement Directive.

19 Directorate-General for Internal Market, Industry, Entrepreneurship and SMEs. Tenders Electronic Daily (TED) (csv subset) - public procurement notices. https://data.europa.eu/ euodp/en/data/dataset/ted-csv. (visited on 6 December 2020)

20 Advanced notes on methodology - Version 0.91 (04/06/2020) https://data.europa.eu/ euodp/repository/ec/dg-grow/mapps/TED_advanced_notes.pdf (visited on 6 December 2020)

21 It must be also noted that number of "awards" in CSV databases can vary from the exact numbers of tenders and contracts concluded on basis of awards because one tender can be split in several lots and several parts. On the other hand, if one "award" was split in several lots or it was won by consortium, this "award" was attributed to each winner, i.e. the total sum of awards to individual winners is higher than the total number of awards. Moreover, the data in databases rely on the meticulousness of contracting authorities in filling forms and at was found that some contracting authorities did not fill data on the country establishment of winner of the bid or flag the winner of the bid as SME or non-SME. All these awards without proper data had to be excluded from the analysis.

22 The amount of the contracts is in some instances deformed by the different approach of contracting authorities in respective countries towards the value of framework agreements - income cases is the value 0 , in some cases is the maximum value of the framework agreement or estimated value thereof. 
ICLR, 2020, Vol. 20, No. 2.

Table 2: Country of establishment of winner (ISO code) - order of countries based on total value of awarded contracts

\begin{tabular}{|c|c|c|c|c|c|c|c|c|c|c|c|c|}
\hline CA & \multicolumn{4}{|c|}{ 1st place } & \multicolumn{4}{|c|}{ 2nd place } & \multicolumn{4}{|c|}{ 3rd place } \\
\hline & 2016 & 2017 & 2018 & 2019 & 2016 & 2017 & 2018 & 2019 & 2016 & 2017 & 2018 & 2019 \\
\hline AT & $\mathrm{AT}$ & AT & AT & AT & $\mathrm{DE}$ & $\mathrm{DE}$ & $\mathrm{DE}$ & $\mathrm{DE}$ & $\mathrm{CZ}$ & IT & $\mathrm{LU}$ & $\mathrm{BE}$ \\
\hline $\mathrm{BE}$ & $\mathrm{BE}$ & $\mathrm{BE}$ & $\mathrm{BE}$ & $\mathrm{BE}$ & $\mathrm{LU}$ & $\mathrm{DE}$ & $\mathrm{LU}$ & FR & FR & NL & IT & NL \\
\hline BG & BG & BG & BG & BG & $\mathrm{HU}$ & AT & PL & IT & RU & FR & ES & ES \\
\hline CY & $\mathrm{CY}$ & $\mathrm{CY}$ & $\mathrm{CY}$ & $\mathrm{CY}$ & GR & GR & UK & $\mathrm{DE}$ & UK & $\mathrm{DE}$ & GR & GR \\
\hline $\mathrm{CZ}$ & $\mathrm{CZ}$ & $\mathrm{CZ}$ & $\mathrm{CZ}$ & $\mathrm{CZ}$ & $\mathrm{DE}$ & SK & SK & IT & FR & $\mathrm{DE}$ & $\mathrm{DE}$ & SK \\
\hline $\mathrm{DE}$ & $\mathrm{DE}$ & $\mathrm{DE}$ & $\mathrm{DE}$ & $\mathrm{DE}$ & AT & NL & AT & AT & FR & AT & UK & $\mathrm{CH}$ \\
\hline DK & DK & DK & DK & DK & NL & $\mathrm{CH}$ & $\mathrm{BE}$ & UK & UK & ES & IT & NO \\
\hline EE & $\mathrm{EE}$ & EE & $\mathrm{EE}$ & $\mathrm{EE}$ & FR & FI & $\mathrm{BE}$ & $\mathrm{BE}$ & $\mathrm{BE}$ & $\mathrm{BE}$ & PL & IT \\
\hline ES & ES & ES & ES & ES & IT & FR & UK & $\mathrm{EE}$ & $\mathrm{BE}$ & $\mathrm{BE}$ & FR & FR \\
\hline FI & FI & FI & FI & FI & IT & US & DK & NL & $\mathrm{EE}$ & SE & NL & ES \\
\hline FR & FR & FR & FR & FR & RO & $\mathrm{BE}$ & IT & NL & $\mathrm{BE}$ & $\mathrm{DE}$ & $\mathrm{CH}$ & IT \\
\hline GR & GR & GR & GR & GR & $\mathrm{CH}$ & IT & NO & CY & UK & CN & FR & IT \\
\hline HR & HR & HR & HR & HR & SI & SI & $\mathrm{CN}$ & SI & IT & AT & SI & AT \\
\hline $\mathrm{HU}$ & $\mathrm{HU}$ & $\mathrm{HU}$ & $\mathrm{HU}$ & $\mathrm{HU}$ & $\mathrm{CH}$ & AT & AT & $\mathrm{CH}$ & PL & RU & $\mathrm{DE}$ & AT \\
\hline IE & IE & IE & IE & IE & UK & UK & UK & UK & NL & $\mathrm{CH}$ & ES & IS \\
\hline IT & IT & IT & IT & IT & PL & ES & FR & US & ES & $\mathrm{DE}$ & ES & $\mathrm{DE}$ \\
\hline LT & LT & LT & LT & LT & LV & PL & PL & LV & $\mathrm{DE}$ & NO & TR & $\mathrm{EE}$ \\
\hline $\mathrm{LU}$ & $\mathrm{LU}$ & $\mathrm{LU}$ & LU & $\mathrm{BE}$ & $\mathrm{BE}$ & $\mathrm{BE}$ & $\mathrm{NL}$ & ES & GR & $\mathrm{DE}$ & $\mathrm{BE}$ & LU \\
\hline LV & LV & LV & LV & LV & $\mathrm{EE}$ & EE & LT & $\mathrm{BE}$ & $\mathrm{HU}$ & PL & $\mathrm{CH}$ & $\mathrm{CZ}$ \\
\hline MT & MT & MT & MT & MT & UK & IT & GR & IT & IT & $\mathrm{BE}$ & IT & ES \\
\hline NL & NL & NL & NL & NL & $\mathrm{BE}$ & US & $\mathrm{DE}$ & $\mathrm{BE}$ & $\mathrm{DE}$ & $\mathrm{BE}$ & $\mathrm{BE}$ & $\mathrm{DE}$ \\
\hline PL & PL & PL & PL & PL & IT & $\mathrm{DE}$ & TR & TR & TR & US & FR & $\mathrm{DE}$ \\
\hline $\mathrm{PT}$ & $\mathrm{PT}$ & $\mathrm{PT}$ & $\mathrm{PT}$ & PT & ES & IT & FR & ES & CA & UK & NO & $\mathrm{CN}$ \\
\hline RO & RO & RO & RO & RO & ES & US & IT & PL & $\mathrm{DE}$ & $\mathrm{CH}$ & ES & TR \\
\hline SE & SE & SE & SE & SE & IT & US & UK & ES & NL & FR & US & DK \\
\hline SI & SI & SI & SI & SI & $\mathrm{CH}$ & US & $\mathrm{CH}$ & GR & $\mathrm{DE}$ & AT & PL & ES \\
\hline SK & SK & SK & SK & SK & UK & CZ & CZ & CZ & CZ & US & PL & CY \\
\hline UK & UK & UK & UK & UK & IE & IE & IE & FR & $\mathrm{DE}$ & US & US & NL \\
\hline
\end{tabular}

Source: authors, TED database

The level of shares of the total amount of value of contract attributed to the economic operators established in particular countries (Table 3) explains certain 
variability of the country of establishment. The share of domestic operators is in the majority of cases over $90 \%$ and only in the case of small and open economies the share is lower than $80 \%$ (Luxembourg and Malta in all years, Cyprus, Estonia, Denmark and Slovakia in one or several years, in the case of the Netherlands, one-year swift in favour of Belgian operators can be linked to long-term interconnection of BENELUX economies, similarly apparent in Luxembourg). Therefore, in general, the foreign operators won only small share of the value of public awards and variability on the second and the third place over years is a result of this small share, rather that result of pattern or development.

Table 3: Share on the total amount of awarded contracts - order of countries based on total value of awarded contracts

\begin{tabular}{|c|c|c|c|c|c|c|c|c|c|c|c|c|}
\hline \multirow[t]{2}{*}{$\mathrm{CA}$} & \multicolumn{4}{|c|}{ 1st place (\%) } & \multicolumn{4}{|c|}{ 2nd place (\%) } & \multicolumn{4}{|c|}{ 3rd place $(\%)$} \\
\hline & 2016 & 2017 & 2018 & 2019 & 2016 & 2017 & 2018 & 2019 & 2016 & 2017 & 2018 & 2019 \\
\hline AT & 96,521 & 95,971 & 91,544 & 95,624 & 1,989 & 3,011 & 6,733 & 2,680 & 0,260 & 0,344 & 0,373 & 0,832 \\
\hline $\mathrm{BE}$ & 83,678 & 85,403 & 80,418 & 81,098 & 6,470 & 10,297 & 26,476 & 10,476 & 3,819 & 5,930 & 12,350 & 6,499 \\
\hline BG & 95,955 & 99,250 & 93,919 & 93,926 & 2,146 & 0,510 & 4,118 & 15,399 & 1,236 & 0,419 & 2,415 & 4,046 \\
\hline $\mathrm{CY}$ & 90,084 & 95,609 & 78,374 & 78,403 & 4,223 & 3,630 & 11,017 & 9,787 & 1,987 & 1,123 & 7,122 & 6,707 \\
\hline $\mathrm{CZ}$ & 82,591 & 94,675 & 96,048 & 99,743 & 7,783 & 4,912 & 5,319 & 0,140 & 7,117 & 4,491 & 1,931 & 0,117 \\
\hline $\mathrm{DE}$ & 99,999 & 98,008 & 99,999 & 99,9995 & 0,0003 & 0,846 & 0,0003 & 0,001 & 0,0001 & 0,307 & 0,0002 & 0,000 \\
\hline DK & 90,544 & 96,177 & 76,319 & 96,795 & 3,955 & 1,120 & 12,741 & 0,809 & 1,369 & 0,619 & 5,337 & 0,474 \\
\hline $\mathrm{EE}$ & 70,618 & 95,348 & 88,556 & 86,685 & 21,753 & 2,856 & 3,737 & 6,433 & 21,389 & 1,855 & 3,119 & 6,060 \\
\hline ES & 97,977 & 98,365 & 98,329 & 97,314 & 0,490 & 0,341 & 0,551 & 0,328 & 0,438 & 0,323 & 0,253 & 0,167 \\
\hline FI & 94,803 & 96,598 & 98,232 & 97,690 & 0,521 & 2,273 & 1,933 & 1,570 & 0,234 & 0,248 & 0,952 & 1,090 \\
\hline FR & 99,721 & 99,990 & 99,991 & 99,998 & 0,135 & 0,009 & 0,004 & 0,001 & 0,049 & 0,002 & 0,003 & 0,000 \\
\hline GR & 95,299 & 93,552 & 92,079 & 93,960 & 0,541 & 5,420 & 5,056 & 1,776 & 0,330 & 0,196 & 1,881 & 1,611 \\
\hline HR & 94,970 & 96,285 & 86,002 & 91,582 & 1,208 & 2,086 & 11,282 & 5,928 & 0,552 & 1,082 & 1,791 & 1,923 \\
\hline $\mathrm{HU}$ & 98,073 & 99,518 & 98,958 & 98,013 & 1,034 & 2,057 & 3,541 & 1,323 & 0,839 & 0,206 & 0,276 & 0,290 \\
\hline IE & 91,507 & 92,687 & 93,029 & 94,636 & 9,464 & 17,277 & 6,310 & 7,091 & 0,515 & 1,586 & 1,588 & 0,141 \\
\hline IT & 98,545 & 99,184 & 98,484 & 95,555 & 0,157 & 0,286 & 0,360 & 0,930 & 0,124 & 0,169 & 0,352 & 0,608 \\
\hline LT & 96,076 & 98,757 & 93,847 & 98,561 & 0,878 & 0,410 & 1,795 & 0,790 & 0,822 & 0,294 & 1,101 & 0,568 \\
\hline $\mathrm{LU}$ & 55,463 & 64,392 & 53,941 & 62,207 & 16,509 & 15,766 & 18,584 & 59,734 & 4,735 & 9,143 & 17,520 & 31,073 \\
\hline $\mathrm{LV}$ & 92,287 & 98,453 & 84,442 & 87,734 & 2,637 & 0,222 & 4,677 & 12,269 & 1,447 & 0,189 & 4,348 & 6,983 \\
\hline MT & 64,337 & 52,500 & 62,385 & 57,189 & 9,122 & 31,101 & 20,171 & 26,275 & 8,886 & 5,000 & 11,031 & 9,038 \\
\hline NL & 97,628 & 99,986 & 98,837 & 67,891 & 1,644 & 0,004 & 0,677 & 32,103 & 0,483 & 0,003 & 0,238 & 0,004 \\
\hline PL & 92,549 & 94,755 & 96,260 & 96,609 & 2,817 & 2,936 & 3,947 & 1,711 & 1,037 & 1,118 & 3,469 & 1,134 \\
\hline $\mathrm{PT}$ & 89,986 & 94,089 & 88,090 & 97,109 & 1,918 & 1,922 & 4,259 & 2,213 & 1,420 & 1,871 & 1,876 & 0,411 \\
\hline $\mathrm{RO}$ & 89,238 & 96,493 & 92,075 & 99,052 & 4,865 & 0,917 & 4,502 & 0,302 & 1,979 & 0,732 & 1,024 & 0,236 \\
\hline SE & 96,234 & 89,112 & 79,312 & 95,854 & 2,418 & 2,780 & 17,391 & 1,203 & 0,367 & 2,573 & 1,021 & 0,771 \\
\hline SI & 88,034 & 93,709 & 84,915 & 90,009 & 2,709 & 3,009 & 8,156 & 4,084 & 1,747 & 1,461 & 7,174 & 2,577 \\
\hline SK & 76,273 & 93,456 & 92,480 & 87,805 & 21,977 & 4,509 & 7,119 & 12,764 & 5,747 & 2,223 & 1,768 & 4,384 \\
\hline UK & 98,002 & 99,667 & 99,936 & 99,971 & 1,421 & 0,165 & 0,037 & 0,027 & 0,318 & 0,130 & 0,024 & 0,014 \\
\hline
\end{tabular}

Source: authors, TED database 
Significant variability of share of SMEs in successful bids occurs across the EU countries (Table 4) and only in few countries it is possible to follow some stability of share of SMEs: cca 15-25\% in Austria, cca $25 \%$ in Belgium and Slovakia, as well as significant share in Malta and Slovenia and constantly low share in Greece, Romania and Spain.

Table 4: Share of value of awards attributed to SMEs

\begin{tabular}{|c|c|c|c|c|}
\hline CA & 2016 & 2017 & 2018 & 2019 \\
\hline AT & $14,61 \%$ & $23,45 \%$ & $27,79 \%$ & $26,68 \%$ \\
\hline BE & $24,79 \%$ & $19,47 \%$ & $26,66 \%$ & $32,57 \%$ \\
\hline BG & $39,35 \%$ & $48,66 \%$ & $55,62 \%$ & $41,64 \%$ \\
\hline CY & $11,13 \%$ & $78,15 \%$ & $71,82 \%$ & $51,34 \%$ \\
\hline CZ & $47,19 \%$ & $34,27 \%$ & $35,59 \%$ & $98,06 \%$ \\
\hline DE & $99,99 \%$ & $29,28 \%$ & $89,83 \%$ & $23,98 \%$ \\
\hline DK & $41,17 \%$ & $22,80 \%$ & $40,53 \%$ & $50,67 \%$ \\
\hline EE & $0,00 \%$ & $84,17 \%$ & $69,62 \%$ & $71,52 \%$ \\
\hline ES & $11,29 \%$ & $18,34 \%$ & $14,50 \%$ & $8,42 \%$ \\
\hline FI & $52,09 \%$ & $27,33 \%$ & $60,48 \%$ & $48,37 \%$ \\
\hline FR & $51,88 \%$ & $80,54 \%$ & $98,64 \%$ & $99,47 \%$ \\
\hline GR & $16,68 \%$ & $22,49 \%$ & $19,76 \%$ & $13,47 \%$ \\
\hline HR & - & $45,18 \%$ & $64,42 \%$ & $46,28 \%$ \\
\hline HU & $40,03 \%$ & $83,82 \%$ & $50,09 \%$ & $17,58 \%$ \\
\hline IE & $43,35 \%$ & $52,88 \%$ & $57,45 \%$ & $40,50 \%$ \\
\hline IT & $1,31 \%$ & $17,01 \%$ & $19,21 \%$ & $34,94 \%$ \\
\hline LT & $28,89 \%$ & $29,80 \%$ & $57,89 \%$ & $69,75 \%$ \\
\hline LU & $38,48 \%$ & $42,23 \%$ & $27,70 \%$ & $29,33 \%$ \\
\hline LV & $100,00 \%$ & $57,06 \%$ & $81,67 \%$ & $83,43 \%$ \\
\hline MT & $100,00 \%$ & $75,26 \%$ & $95,60 \%$ & $78,22 \%$ \\
\hline NL & $82,08 \%$ & $99,65 \%$ & $66,35 \%$ & $67,76 \%$ \\
\hline PL & $33,16 \%$ & $48,24 \%$ & $50,28 \%$ & $43,26 \%$ \\
\hline PT & $52,90 \%$ & $10,11 \%$ & $30,26 \%$ & $15,20 \%$ \\
\hline RO & $0,00 \%$ & $14,38 \%$ & $4,53 \%$ & $4,92 \%$ \\
\hline SE & $87,61 \%$ & $48,72 \%$ & $44,05 \%$ & $56,62 \%$ \\
\hline SI & $34,58 \%$ & $66,72 \%$ & $65,75 \%$ & $72,42 \%$ \\
\hline SK & $52,78 \%$ & $43,51 \%$ & $47,47 \%$ & $55,81 \%$ \\
\hline UK & $48,96 \%$ & $31,54 \%$ & $5,67 \%$ & $96,96 \%$ \\
\hline Se: $\% \%$ \\
\hline & $150 \%$ & & \\
\hline
\end{tabular}

Source: authors, TED database

Due to abovementioned findings, the analysis of the impact of limited tendering will be restricted to assessment, whether it strengthens the position of domestic economic operators and whether it has impact on the position of the SMEs. In the majority of countries is the market position of non-domestic 
economic operators limited and therefore it is not meaningful to assess changes in the structure of this part of the market.

Only in the few EU countries limited tendering lead to constantly higher share of domestic economic operators (Table 5). The constant market share of domestic economic operators comparing to share in the field of all types of procedures is visibly in Cyprus, only. This pattern corresponds to the highest share of tenders without prior call occurring in Cyprus (Graph 1). Equally, stronger position of domestic companies in directs awards, comparing to overall share, in Slovakia corresponds to relatively high level of awards without prior publication in 2016 (see Graph 1). Constantly higher ratio of awards to domestic economic operators comparing to their market share in all tenders and constant high level of procedures without prior publication can flag lack of transparency of public procurement and significant risk of abuse of this type of procedure.

Table 5: Share of value of awards attributed to domestic economic operators under limited tendering

\begin{tabular}{|c|c|c|c|c|c|c|c|c|}
\hline \multirow{2}{*}{ CA } & \multicolumn{2}{|c}{2016} & \multicolumn{2}{c|}{2017} & \multicolumn{2}{c|}{2018} & \multicolumn{2}{c|}{2019} \\
\hline & Share & delta & Share & delta & Share & delta & Share & delta \\
\hline AT & $93,866 \%$ & $-2,66$ & $70,464 \%$ & $-25,51$ & $68,819 \%$ & $-22,72$ & $98,255 \%$ & 2,63 \\
\hline BE & $56,179 \%$ & $-27,50$ & $77,155 \%$ & $-8,25$ & $97,198 \%$ & 16,78 & $88,602 \%$ & 7,50 \\
\hline BG & $80,185 \%$ & $-15,77$ & $96,893 \%$ & $-2,36$ & $78,569 \%$ & $-15,35$ & $74,727 \%$ & $-19,20$ \\
\hline CY & $92,766 \%$ & 2,68 & $98,206 \%$ & 2,60 & $87,170 \%$ & 8,80 & $84,559 \%$ & 6,16 \\
\hline CZ & $63,222 \%$ & $-19,37$ & $71,243 \%$ & $-23,43$ & $88,992 \%$ & $-7,06$ & $89,034 \%$ & $-10,71$ \\
\hline DE & $97,695 \%$ & $-2,30$ & $98,679 \%$ & 0,67 & $99,998 \%$ & 0,00 & $92,261 \%$ & $-7,74$ \\
\hline DK & $64,536 \%$ & $-26,01$ & $48,170 \%$ & $-48,01$ & $56,119 \%$ & $-20,20$ & $43,858 \%$ & $-52,94$ \\
\hline EE & $73,924 \%$ & 3,31 & $82,393 \%$ & $-12,95$ & $85,663 \%$ & $-2,89$ & $86,585 \%$ & $-0,10$ \\
\hline ES & $97,833 \%$ & $-0,14$ & $96,101 \%$ & $-2,26$ & $96,503 \%$ & $-1,83$ & $48,700 \%$ & $-48,61$ \\
\hline FI & $21,841 \%$ & $-72,96$ & $94,316 \%$ & $-2,28$ & $77,369 \%$ & $-20,86$ & $87,730 \%$ & $-9,96$ \\
\hline FR & $99,523 \%$ & $-0,20$ & $98,627 \%$ & $-1,36$ & $94,975 \%$ & $-5,02$ & $99,610 \%$ & $-0,39$ \\
\hline GR & $100,000 \%$ & 4,70 & $99,693 \%$ & 6,14 & $94,668 \%$ & 2,59 & $58,735 \%$ & $-35,22$ \\
\hline HR & $64,836 \%$ & $-30,13$ & $90,870 \%$ & $-5,42$ & $75,934 \%$ & $-10,07$ & $93,800 \%$ & 2,22 \\
\hline HU & $93,616 \%$ & $-4,46$ & $92,052 \%$ & $-7,47$ & $93,910 \%$ & $-5,05$ & $88,010 \%$ & $-10,00$ \\
\hline IE & $0,000 \%$ & $-91,51$ & $100,000 \%$ & 7,31 & $100,000 \%$ & 6,97 & $66,628 \%$ & $-28,01$ \\
\hline IT & $88,383 \%$ & $-10,16$ & $98,356 \%$ & $-0,83$ & $95,665 \%$ & $-2,82$ & $84,220 \%$ & $-11,33$ \\
\hline LT & $53,473 \%$ & $-42,60$ & $72,086 \%$ & $-26,67$ & $37,646 \%$ & $-56,20$ & $73,265 \%$ & $-25,30$ \\
\hline LU & $40,260 \%$ & $-15,20$ & $48,190 \%$ & $-16,20$ & $77,328 \%$ & 23,39 & $87,845 \%$ & 25,64 \\
\hline LV & $75,681 \%$ & $-16,61$ & $83,862 \%$ & $-14,59$ & $76,738 \%$ & $-7,70$ & $75,128 \%$ & $-12,61$ \\
\hline MT & $65,189 \%$ & 0,85 & $55,307 \%$ & 2,81 & $61,606 \%$ & $-0,78$ & $72,839 \%$ & 15,65 \\
\hline NL & $98,431 \%$ & 0,80 & $94,786 \%$ & $-5,20$ & $97,536 \%$ & $-1,30$ & $99,952 \%$ & 32,06 \\
\hline PL & $81,328 \%$ & $-11,22$ & $89,767 \%$ & $-4,99$ & $90,585 \%$ & $-5,67$ & $92,727 \%$ & $-3,88$ \\
\hline
\end{tabular}

23 Difference between market shares for domestic economic operators in limited tenders and share in all tenders (Table 3) 
ICLR, 2020, Vol. 20, No. 2.

\begin{tabular}{|c|c|c|c|c|c|c|c|c|}
\hline PT & $85,001 \%$ & $-4,98$ & $87,787 \%$ & $-6,30$ & $82,368 \%$ & $-5,72$ & $22,150 \%$ & $-74,96$ \\
\hline RO & $73,308 \%$ & $-15,93$ & $76,960 \%$ & $-19,53$ & $94,696 \%$ & 2,62 & $96,266 \%$ & $-2,79$ \\
\hline SE & $0,000 \%$ & $-96,23$ & $90,303 \%$ & 1,19 & $98,112 \%$ & 18,80 & $95,012 \%$ & $-0,84$ \\
\hline SI & $66,251 \%$ & $-21,78$ & $83,110 \%$ & $-10,60$ & $80,587 \%$ & $-4,33$ & $85,788 \%$ & $-4,22$ \\
\hline SK & $98,988 \%$ & 22,71 & $96,252 \%$ & 2,80 & $98,968 \%$ & 6,49 & $79,491 \%$ & $-8,31$ \\
\hline UK & $90,682 \%$ & $-7,32$ & $90,279 \%$ & $-9,39$ & $84,537 \%$ & $-15,40$ & $90,407 \%$ & $-9,56$ \\
\hline
\end{tabular}

Source: authors, TED database

However, tenders without prior publication significantly outmanoeuvres SMEs (Table 6) from this sector of public procurement. Both impact of the tenders without prior call must be, nevertheless, read together with the share of tenders without call on all procurements because it mirrors the intensity of analysed effects.

Table 6: Share of value of awards attributed to SMEs under limited tendering

\begin{tabular}{|c|c|c|c|c|c|c|c|c|}
\hline \multirow{2}{*}{ CA } & \multicolumn{2}{|c}{2016} & \multicolumn{2}{c|}{2017} & \multicolumn{2}{c|}{2018} & \multicolumn{2}{c|}{2019} \\
\hline & Share & delta $^{24}$ & Share & delta & Share & delta & Share & delta \\
\hline AT & $45,294 \%$ & 30,69 & $14,811 \%$ & $-8,64$ & $9,110 \%$ & $-18,68$ & $12,922 \%$ & $-13,76$ \\
\hline BE & $0,611 \%$ & $-24,18$ & $1,035 \%$ & $-18,44$ & $2,771 \%$ & $-23,89$ & $5,566 \%$ & $-27,00$ \\
\hline BG & $7,490 \%$ & $-31,86$ & $28,100 \%$ & $-20,56$ & $43,503 \%$ & $-12,12$ & $27,783 \%$ & $-13,85$ \\
\hline CY & $0,000 \%$ & $-11,13$ & $42,715 \%$ & $-35,43$ & $96,001 \%$ & 24,18 & $85,468 \%$ & 34,13 \\
\hline CZ & $1,782 \%$ & $-45,41$ & $24,660 \%$ & $-9,61$ & $13,709 \%$ & $-21,88$ & $25,733 \%$ & $-72,32$ \\
\hline DE & $9,058 \%$ & $-90,93$ & $6,749 \%$ & $-22,53$ & $99,989 \%$ & 10,16 & $31,542 \%$ & 7,56 \\
\hline DK & $2,543 \%$ & $-38,62$ & $9,462 \%$ & $-13,34$ & $2,666 \%$ & $-37,86$ & $3,154 \%$ & $-47,51$ \\
\hline EE & $0,000 \%$ & 0,00 & $23,802 \%$ & $-60,36$ & $86,979 \%$ & 17,36 & $72,337 \%$ & 0,82 \\
\hline ES & $1,002 \%$ & $-10,29$ & $1,305 \%$ & $-17,03$ & $4,851 \%$ & $-9,65$ & $5,692 \%$ & $-2,73$ \\
\hline FI & $0,606 \%$ & $-51,49$ & $6,536 \%$ & $-20,79$ & $10,895 \%$ & $-49,59$ & $9,912 \%$ & $-38,46$ \\
\hline FR & $15,288 \%$ & $-36,59$ & $17,824 \%$ & $-62,72$ & $28,176 \%$ & $-70,47$ & $13,094 \%$ & $-86,37$ \\
\hline GR & $0,000 \%$ & $-16,68$ & $0,000 \%$ & $-22,49$ & $34,465 \%$ & 14,70 & $11,994 \%$ & $-1,48$ \\
\hline HR & $0,000 \%$ & - & $7,249 \%$ & $-37,93$ & $19,149 \%$ & $-45,27$ & $13,380 \%$ & $-32,90$ \\
\hline HU & $36,921 \%$ & $-3,11$ & $42,629 \%$ & $-41,19$ & $54,256 \%$ & 4,16 & $27,183 \%$ & 9,60 \\
\hline IE & - & - & $0,000 \%$ & $-52,88$ & $5,007 \%$ & $-52,44$ & $1,170 \%$ & $-39,33$ \\
\hline IT & $5,308 \%$ & 4,00 & $12,235 \%$ & $-4,78$ & $19,818 \%$ & 0,61 & $22,073 \%$ & $-12,87$ \\
\hline LT & $0,000 \%$ & $-28,89$ & $0,079 \%$ & $-29,73$ & $14,859 \%$ & $-43,03$ & $24,915 \%$ & $-44,83$ \\
\hline LU & $6,687 \%$ & $-31,79$ & $8,193 \%$ & $-34,04$ & $10,520 \%$ & $-17,18$ & $5,823 \%$ & $-23,51$ \\
\hline LV & $0,000 \%$ & $-100,00$ & $52,754 \%$ & $-4,31$ & $73,303 \%$ & $-8,37$ & $63,737 \%$ & $-19,69$ \\
\hline MT & $65,189 \%$ & $-34,81$ & $44,693 \%$ & $-30,57$ & $33,977 \%$ & $-61,62$ & $19,702 \%$ & $-58,51$ \\
\hline NL & $77,613 \%$ & $-4,46$ & $88,938 \%$ & $-10,71$ & $33,191 \%$ & $-33,16$ & $99,859 \%$ & 32,10 \\
\hline
\end{tabular}

24 Difference between market shares for SMEs in limited tenders and share in all tenders (Table 4) 
ICLR, 2020, Vol. 20, No. 2.

\begin{tabular}{|c|c|c|c|c|c|c|c|c|}
\hline PL & $3,756 \%$ & $-29,41$ & $5,701 \%$ & $-42,54$ & $12,259 \%$ & $-38,02$ & $16,833 \%$ & $-26,43$ \\
\hline PT & $1,335 \%$ & $-51,57$ & $4,383 \%$ & $-5,73$ & $3,747 \%$ & $-26,51$ & $2,768 \%$ & $-12,43$ \\
\hline RO & $0,000 \%$ & 0,00 & $0,000 \%$ & $-14,38$ & $0,357 \%$ & $-4,17$ & $1,047 \%$ & $-3,87$ \\
\hline SE & - & - & $8,788 \%$ & $-39,93$ & $0,300 \%$ & $-43,75$ & $17,920 \%$ & $-38,70$ \\
\hline SI & $29,573 \%$ & $-5,01$ & $50,197 \%$ & $-16,52$ & $31,126 \%$ & $-34,62$ & $53,569 \%$ & $-18,85$ \\
\hline SK & $81,675 \%$ & 28,90 & $32,952 \%$ & $-10,56$ & $31,351 \%$ & $-16,12$ & $37,321 \%$ & $-18,49$ \\
\hline UK & $9,337 \%$ & $-39,62$ & $1,077 \%$ & $-30,46$ & $14,291 \%$ & 8,62 & $12,114 \%$ & $-84,85$ \\
\hline
\end{tabular}

Source: authors, TED database

To sum up this part, direct awards without prior publication of call have impact not only to the number of tenderers but also on the structure of suppliers within the internal market. This impact is, however, limited due to the fact that there is overall strong presence of local economic operators in tenders. Thus, only small margin of the "public procurement market" is occupied by the economic operators established outside the country of the contracting authority. Overall impact of limited tendering is volatile across the EU, however in the countries with higher ratio of direct awards it led also to the stronger position of local companies. Negative impact of limited tendering is definitely apparent regarding SMEs since their share drops in the case of tenders without prior publication of call.

\section{Extreme urgency}

Since most of the above-mentioned exemptions has technical character and the fulfilment of conditions for their application can be relatively easily verified, authors chose for their deeper analysis an exemption justified by the extreme urgency.

Pursuant to Article 32.2(c) of Public Procurement Directive [2014] the negotiated procedure without prior publication may be used for public works contracts, public supply contracts and public service contracts in so far as is strictly necessary where, for reasons of extreme urgency brought about by events unforeseeable by the contracting authority, the time limits for the open or restricted procedures or competitive procedures with negotiation cannot be complied with. The circumstances invoked to justify extreme urgency shall not in any event be attributable to the contracting authority.

The application of this exemption is legitimate only if three conditions are fulfilled concurrently. As the CJEU specified in Commission v Italy ${ }^{25}$ [1993] it requires the (i) existence of an unforeseeable event, (ii) extreme urgency rendering the observance of time-limits laid down by other procedures impossible, and, finally, (iii) a causal link between the unforeseeable event and extreme

25 Case C-107/92, para. 12 
urgency resulting therefrom. If one of those conditions is not satisfied, contracting authorities may not derogate from the provisions of the directive (Commission $v$ Spain $^{26}$ [1992]). Moreover, if one of those conditions is not satisfied, nor it is necessary to determine, whether the other derogation conditions were satisfied.

CJEU considered an unforeseeable event in Commission $v$ Germany ${ }^{27}$ [1996]. In this case, German contracting authority awarded the public works contract for the dredging of the river Ems by negotiated procedure without prior publication of a tender notice with reference to extreme urgency by reasoning, that contracting authority could not have foreseen (to him) the totally unexpected refusal by the Regional Authority to grant its approval to a ongoing project on deepening river Ems. CJEU stressed that the possibility that a body which must approve a project might, before expiry of the period laid down for this purpose, raise objections for reasons which it is entitled to put forward is, consequently, something which is foreseeable in plan approval procedure. The legitimate refusal of the Regional Authority to approve the project for dredging the lower Ems, thereby obliging the competent authorities to amend that project, cannot therefore be regarded as an unforeseen event.

When explaining the extreme urgency exemption, two Italian cases may serve as case studies.

In Commission $\boldsymbol{v}$ Italy ${ }^{28}$ [2004] the Commission brought an action against Italy declaring that Italian contracting authority awarded contracts for the completion of the construction of an overflow basin to hold flood waters of the Parma watercourse in the Marano area as well as for works relating to the development and completion of an overflow basin for the Enza watercourse and to the retention of flood waters of the Terdoppio watercourse southwest of Cerano by the negotiated procedure without prior publication of a contract notice, when the conditions necessary in that regard were not satisfied.

Between 1981 and 1990 the contracting authority initiated procedures for the implementation of flood safety measures for the territories and zones affected by the floodwaters of the River Po and its tributaries through contracts for the development of the overall project and the carrying out of the works in lots as and when funding became available. The contracts relating to the development of the project and to the first lot of the works were awarded following a procedure which complied with [Union's] law. The relevant contract notices contained a provision allowing the contracting authority to award the carrying out of the subsequent lots of the work to the same undertaking. In this relation, contracting authority in 1997 approved contracts procured through the negotiated

26 Case C-24/91, para. 13

27 Case C-318/94

28 Case C-385/02

Published by Palacký University Olomouc, Czech Republic, 2020.

ISSN (print): 1213-8770; ISSN (online): 2464-6601 
procedure without prior publication of a contract notice. Contracting authority reasoned, besides other, that the works required to be completed urgently in this case, to avoid the increased risk of flooding which would occur if they were not finished.

As the CJEU pointed out the original contracts relating to the flood protection works had been awarded in the1980s, and it had been anticipated from the start that the works would be carried out in lots as and when funding became available. Those matters do not establish any extreme urgency. On the contrary, they arise out of the arrangements put into place by the contracting authority and therefore argumentation based on extreme urgency exemption was not well founded and was rejected.

To comparison, in Commission v Italy ${ }^{29}$ [2005] extreme urgency was considered differently. In June 2002 Italian President of the Council of Ministers declared a state of emergency on the national territory for the purpose of aerial forest firefighting. That ordinance authorised the contracting authority (i) to purchase aircraft to combat forest fires by private negotiated contract, by derogation from the statutory provisions listed in that ordinance, that is to say in particular from the national legislation transposing Directives governing public procurement (92/50 and 93/36) and, (ii) to obtain, also by privately negotiated contract, two-way radio equipment for communication with firefighting aircraft. It moreover permitted the contracting authority to have recourse to private negotiation for the acquisition of equipment to reinforce its technological and computing resources, and for the acquisition and implementation of aerial forest firefighting services. Commission considered that the provision of the contested ordinance authorising the award of this supply contract by the negotiated procedure was contrary to public procurement directives and to provisions on free movement of services and freedom of establishment. At the end, Commission's action was dismissed by the CJEU, as the effect of the contested ordinance expired before the Commission's letter of formal notice was sent. However, Advocate General Jacobs provided an analysis of an extreme urgency standard, which might be used as useful interpretation tool.

General Advocate Jacobs pointed out that it seems incontrovertible that widespread outbreaks of forest fires may be reasons of extreme urgency giving rise to a need for the acquisition of firefighting services and equipment if they are not already sufficiently available. On the other side, outbreaks of forest fires in summer are a regularly recurring event throughout southern Europe; they are thus foreseeable, and any urgency in the need to acquire means to combat them is attributable to the Italian authorities. Regular seasonal occurrences therefore cannot be considered unforeseeable events. However, it cannot be denied that even such occurrences may in some years be of such exceptional intensity or extent as to be legitimately regarded as unforeseeable. It may be accepted

29 Case C-525/03 
that forest fires in summer are foreseeable in Italy, so that the authorities cannot rely on their own failure to provide in advance for such fires in order to justify recourse to a negotiated procedure. Exceptional forest fires due to exceptional weather conditions are however by definition not foreseeable as such and may provide reasons of extreme urgency for the purposes of that provision.

Referring to a causal link, authors agree with Načiščionis et al. ${ }^{30}$ that harmful consequences that could occur without an adequate reaction from state administration to an extraordinary circumstances or event must be taken into consideration.

To sum up, the application of extreme urgency exemption requires individual and case-by-case assessment of fulfilment of all three conditions. To this regard, due diligence, and duty of sound administration of contracting authority during the project planning must be taken into consideration, as unforeseeable circumstances refers to those that could not have been predicted despite reasonably diligent preparation of the initial award by the contracting authority. When assessing the urgency whose degree must by qualified by the level of "extreme" (as "usual" urgency results in different legal consequences), the exceptional intensity of the situation might be the decisive criterion. Neglective approach of contracting authority to project planning as well as the existence of the regular situation may therefore never justify the uncompetitive procurement and the use of exemption based on extreme urgency.

\section{Limited tendering and covid-19}

There is no doubt that the pandemic situation is an "extreme situation" and "extreme urgency" provisions of public procurement rules can be triggered. The European Commission promptly reacted to pandemic situation and issued a Guidance on using public procurement framework in the emergency situation related to the COVID-19 crisis [2020]. Under this Guidance, negotiated procedure without publication can be used, when, due to the urgency, a substantial reduce of deadlines in open or restricted procedures should not be sufficient. Even a direct award to a preselected economic operator could be allowed, provided such operator is the only one able to deliver the required supplies within the technical and time constraints imposed by the extreme urgency.

The extreme urgency requirements are then elaborated in Section 2.3 of the Guidance. The Commission reminded, that this procedure remains exceptional

30 NAČIŠČIONIS, Jānis, TUMALAVIČIUS, Vladas, SKRASTINA, Una, RADZEVIČS, Juris, PRAKAPIENE, Daila. Issues of Public Security: Legal Consequences of Determining Unforseeable Extraordinary Events. Journal of Security and Sustainability Issues, 2020, vol. 9, no.3, pp.1110, DOI: 10.9770/jssi.2020.9.3(34), ISSN: 2020-7025. [online] Available at: https://jssidoi.org/jssi/uploads/papers/36/Naciscionis_Issues_of_Public_Security_Legal_ Consequences_of_Determining_Unforeseeable_Extraordinary_Events.pdf Accessed: 10.12.2020 
as contracting authorities by using it derogate from basic principle of transparency. Thus, it is applicable if only one undertaking is able do deliver within the technical and time constraints imposed by the extreme urgency. Furthermore, each contracting authority must evaluate in the individual assessment whether each of the conditions for using such a 'negotiated procedure without prior publication' are met. What is beyond "usual" conditions (events unforeseeable by the contracting authority in question, ${ }^{31}$ extreme urgency making compliance with general deadlines impossible, ${ }^{32}$ causal link between the unforeseen event and the extreme urgency ${ }^{33}$ ) - guidelines recognises one additional condition: negotiated procedures without prior publication may offer the possibility to meet immediate needs. They cover the gap until more stable solutions can be found, such as framework contracts for supplies and services, awarded through regular procedures (including accelerated procedures).

At this point we can only agree with other authors ${ }^{34}$ that Commission's Guidance is good, clear and actionable. However, not every Member State follows it.

"That's gonna cost a lot." / "Never mind. They [35] gonna look for money for it ..." This cynical dialogue between then time Slovak Prime Minister Mr. Pellegrini and then time Minister of Interior Ms. Saková was caught by accident during the press conference on 11 March 2020 announcing measures against corona pandemic, ${ }^{36}$ i.e. in the time when coronavirus pandemic started to spread in Slovakia. The pandemic situation in Europe caused pressure on public funds and effective spending. Negligent approach to public spending or intentional abuses of public funds could have be easily covered and rebutted by reference to necessity, priority to protect human lives.

31 The number of COVID-19 patients requiring medical treatment is rising daily and, in most Member States, is expected to increase further until the peak will be reached. These events and especially their specific development has to be considered unforeseeable for any contracting authority.

32 It cannot be doubted that the immediate needs the hospitals and health institutions (supplies, services and public works) have to be met with all possible speed. Whether this makes it impossible to respect even the very short deadlines of the accelerated open or restricted procedure (15 and 10 days respectively to submit the offers) will have to be assessed on a case-by-case basis, but it is likely in most cases, at least as regards the significantly increased short-term needs as the infection curve rises. If extreme urgency is invoked, the procurement need has to be satisfied without delay. The exception cannot be invoked for the award of contracts that take longer than they would have taken if a transparent, open or restricted, procedure had been used, including accelerated (open or restricted) procedures.

33 For the satisfaction of the immediate needs of hospitals and health institutions within a very short timeframe the causal link with the COVID-19 pandemic cannot reasonably be doubted

34 E.g. SANCHEZ-GRAELLS, Albert. European Commission's Guidance on Extreme Emergency Procurement and Covid-19 - Some Thoughts and a Word on the Dyson Contract. 2020. [online] Available at: https://www.howtocrackanut.com/blog/2020/4/1/european-commissions-guidance-on-extreme-emergency-procurement-and-covid-19-somethoughts. Accessed: 10.12.2020

35 Politicians referred to new-elected political garniture.

36 DenníkN [online] https://dennikn.sk/minuta/1795303/ Accessed: 10.12.2020 
In several EU countries, however, doubts on effective spending during the corona crisis occurred including cases when the medical equipment was not bought from well-established provider of medical material bud from newly established company without any previous presence on the market of medical equipment, e.g. company run by owner of casinos in Slovenia, company focused previously on practice aromatherapy and crystal therapy in Romania ${ }^{37}$ or company registered only few days before contract in Slovakia. ${ }^{38}$

According to data in the TED database, the EU Member States employed different approaches to purchase medical and other equipment related to combat against the coronavirus pandemic. ${ }^{39}$ In concreto, whether they relied on direct award owing to the "extreme urgency" or used other more competitive procedure (Table 7). Moreover, in the first half of year 2020, the spread of pandemic undeniably was an unexpected situation and there was an urgent need for purchasing suitable, however, on the other hand, in the second half of the year, policy makers have decent amount of time to prepare and to adapt their policies, including procurement of medical material (Graph 3).

Graph 2: Comparison between number of open procedures and negotiated procedures without prior call for competition - medical products for combating against COVID-19 in 2020 (Source: authors, TED database)

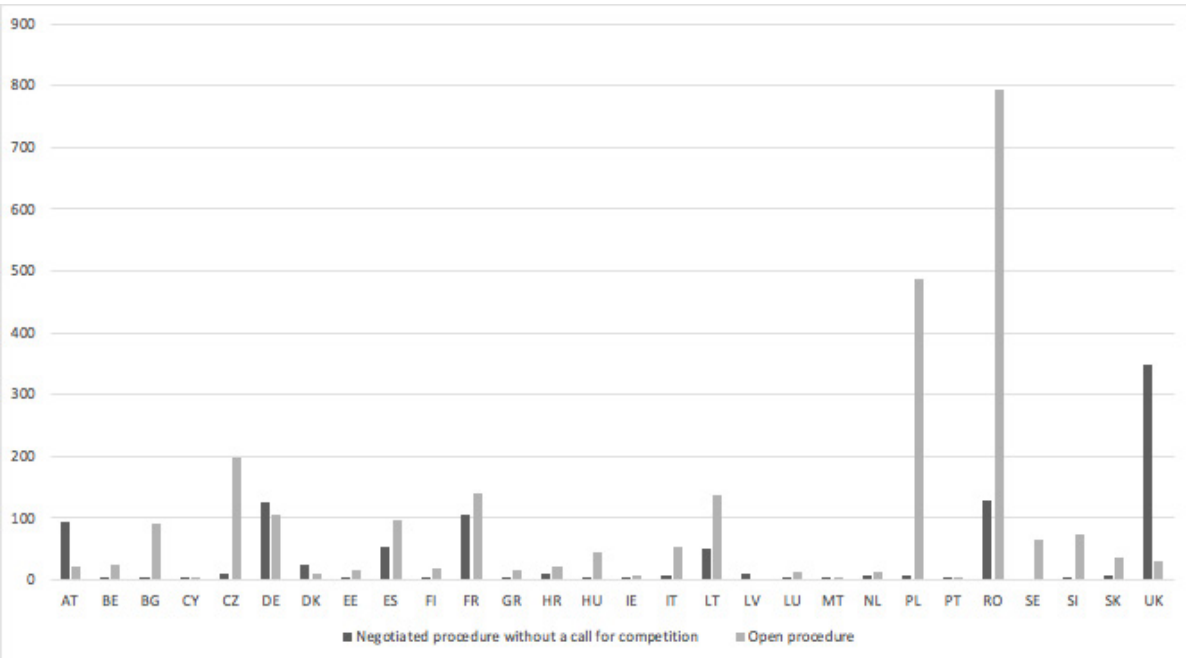

37 LOZOVSKY, Ilya. In Europe's Scramble to Buy COVID-19 Supplies, Anti-Corruption Measures Fall Away. 21 April 2020. OCCRP. https://www.occrp.org/en/coronavirus/ in-europes-scramble-to-buy-COVID-19-supplies-anti-corruption-measures-fall-away Accessed: 10.12 .2020

38 DOSTÁL, Ondrej. Koronavírus: smerácky biznis na rozlúčku? Denník N, 16 March 2020. https://dennikn.sk/1803703/koronavirus-smeracky-biznis-na-rozlucku Accessed: 10.12.2020

39 CVP codes 33157400, 33670000, 33631600, 33195110, 35113400, 18424300, 33141420, 33192120, 39330000, 33191000, 18143000, 45215142, 33157110, 33157000, 33694000. 
ICLR, 2020, Vol. 20, No. 2.

Table 7: Procedures regarding medical and other equipment related to combat against COVID-19

\begin{tabular}{|c|c|c|c|c|c|c|c|c|c|}
\hline \multicolumn{2}{|c|}{} & \multicolumn{2}{|c|}{$\begin{array}{c}\text { Negotiated proce- } \\
\text { dure without a call } \\
\text { for competition }\end{array}$} & \multicolumn{3}{c|}{ Open procedure } & \multicolumn{2}{c|}{$\begin{array}{c}\text { Competitive procedure } \\
\text { with negotiation }\end{array}$} \\
\hline & Total & II-VI & VII-XII & Total & II-VI & VII-XII & Total & II-VI & VII-XII \\
\hline AT & 94 & 21 & 73 & 21 & 5 & 16 & 4 & 3 & 1 \\
\hline BE & 1 & 1 & & 25 & 13 & 12 & 2 & 1 & 1 \\
\hline BG & 2 & & 2 & 91 & 40 & 51 & & & \\
\hline CY & 2 & 1 & 1 & 1 & & 1 & & & \\
\hline CZ & 9 & 2 & 7 & 199 & 100 & 99 & & & \\
\hline DE & 126 & 103 & 23 & 104 & 52 & 52 & 3 & 3 & \\
\hline DK & 24 & & 24 & 10 & 6 & 4 & 2 & 1 & 1 \\
\hline EE & 4 & 3 & 1 & 17 & 14 & 3 & & & \\
\hline ES & 53 & 34 & 19 & 98 & 48 & 50 & 2 & 2 & \\
\hline FI & 1 & & 1 & 19 & 8 & 11 & 2 & 2 & \\
\hline FR & 104 & 25 & 79 & 141 & 60 & 81 & 1 & 1 & \\
\hline GR & 2 & 1 & 1 & 16 & 9 & 7 & & & \\
\hline HR & 10 & 2 & 8 & 21 & 8 & 13 & & & \\
\hline HU & 5 & 5 & & 46 & 25 & 21 & & & \\
\hline IE & 2 & & 2 & 7 & 1 & 6 & & & \\
\hline IT & 7 & 1 & 6 & 53 & 29 & 24 & & & \\
\hline LT & 51 & 45 & 6 & 137 & 53 & 84 & & & \\
\hline LV & 10 & 4 & 3 & & 7 & & & & \\
\hline LU & 4 & 7 & & 14 & & 7 & & & \\
\hline MT & 1 & & 1 & 3 & 1 & 2 & & & \\
\hline NL & 7 & & 7 & 14 & 7 & 7 & & & \\
\hline PL & 6 & 2 & 4 & 486 & 192 & 294 & & & \\
\hline PT & 1 & 1 & & 3 & & 3 & & & \\
\hline RO & 128 & 53 & 75 & 793 & 329 & 464 & & & \\
\hline SE & & & & 66 & 36 & 30 & & & \\
\hline SI & 5 & 2 & 3 & 74 & 29 & 45 & & & \\
\hline SK & 8 & 5 & 3 & 36 & 19 & 17 & & & \\
\hline UK & 347 & 118 & 229 & 30 & 17 & 13 & & & \\
\hline & & & & & & & & & \\
\hline
\end{tabular}

Published by Palacký University Olomouc, Czech Republic, 2020.

ISSN (print): 1213-8770; ISSN (online): 2464-6601 
ICLR, 2020, Vol. 20, No. 2.

\begin{tabular}{|c|c|c|c|c|c|c|}
\hline & \multicolumn{3}{|c|}{ Restricted procedure } & \multicolumn{3}{|c|}{ Negotiated procedure } \\
\hline & Total & II-VI & VII-XII & Total & II-VI & VII-XII \\
\hline \multicolumn{7}{|l|}{ AT } \\
\hline \multicolumn{7}{|l|}{$\mathrm{BE}$} \\
\hline BG & 3 & 1 & 2 & 3 & & 3 \\
\hline \multicolumn{7}{|l|}{$\mathrm{CY}$} \\
\hline $\mathrm{CZ}$ & 37 & 6 & 31 & 4 & 1 & 3 \\
\hline $\mathrm{DE}$ & & & & 1 & & 1 \\
\hline $\mathrm{DK}$ & 2 & 1 & 1 & 1 & & 1 \\
\hline \multicolumn{7}{|l|}{$\mathrm{EE}$} \\
\hline ES & & & & 1 & & 1 \\
\hline FI & 2 & & 2 & & & \\
\hline FR & 1 & 1 & & 9 & 6 & 3 \\
\hline \multicolumn{7}{|l|}{ GR } \\
\hline HR & 1 & & 1 & & & \\
\hline \multicolumn{7}{|l|}{$\mathrm{HU}$} \\
\hline \multicolumn{7}{|l|}{ IE } \\
\hline IT & 3 & 1 & 2 & & & \\
\hline LT & 1 & & 1 & & & \\
\hline \multicolumn{7}{|l|}{ LV } \\
\hline LU & & & & 1 & & 1 \\
\hline \multicolumn{7}{|l|}{ MT } \\
\hline NL & 1 & & 1 & & & \\
\hline $\mathrm{PL}$ & 3 & 1 & 2 & & & \\
\hline \multicolumn{7}{|l|}{ PT } \\
\hline $\mathrm{RO}$ & 1 & & 1 & & & \\
\hline SE & & & & 2 & 2 & \\
\hline SI & 3 & 1 & 2 & & & \\
\hline SK & 6 & & 6 & & & \\
\hline UK & 2 & 1 & 1 & & & \\
\hline
\end{tabular}

Source: authors, TED database

Published by Palacký University Olomouc, Czech Republic, 2020.

ISSN (print): 1213-8770; ISSN (online): 2464-6601 
ICLR, 2020, Vol. 20, No. 2.

Graph 3: Number of negotiated procedures without prior call for competition - medical products for combating against COVID-19 in 2020 - comparison - first and second half of 2020

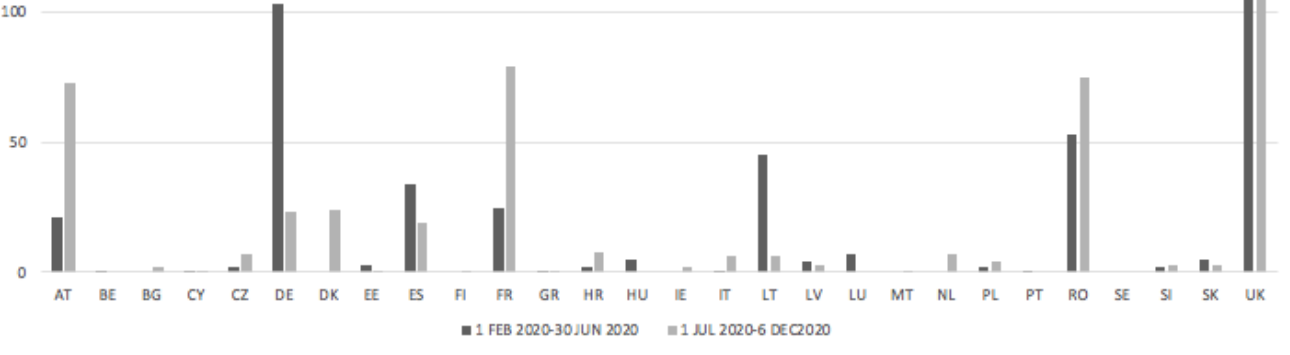

Source: authors, TED database

\section{Conclusion}

It appears that public procurement in most of the EU countries really is an efficient tool for value for money achievement, as limited tendering through negotiation procedure without prior call for publication do not cross $5 \%$ share or all tenders. However, as one can see in Graph 1 this is not the case of Bulgaria, Cyprus, Romania and Slovenia.

On the other side, a deeper analysis proved, that almost all member states, when realising limited tendering, award contracts to domestic suppliers (Table 5). This appeared especially in relation with COVID-19 procurement. Despite quite clear Commission's Guidelines, research proved, that that several EU countries employed limited tendering even in the second part of year 2020 when it could have been expected that there would be necessity of purchases of medical material and other goods necessary for the combat against COVID-19 pandemic. It can be expected that some cases of limited tendering will be challenged due to abuse of the "extreme urgency" clause. The duty of contracting authorities to use extraordinary measures (including limited tendering) for limited time only was also suggested by the European Commission in its Guidance referring necessity to establish stable solutions again via standard procedures, e.g. framework agreements. 
Regarded all fact, we can conclude, that despite accurate legislation, limited tendering in practice is a barrier to achieve best value for money since it impedes intra-EU trade and diminishes business opportunities of SMEs.

\section{The Acknowledgment}

This contribution presents some results from research projects: APVV-170641 "Improvement of effectiveness of legal regulation of public procurement and its application within EU law context", Jean Monnet project No. 600587-EPP1-2018-1-SK-EPPJMO-MODULE: „Clinical Education in Selected Areas of European Union's Internal Market“ and VEGA project No. 2/0167/19: „The real convergence in the European union: empirical proofs and implications“.

The authors acknowledge to anonymous reviewer for their thoughtful suggestions and comments.

\section{List of references}

BOVIS, Christopher. EU Public Procurement Law. Edward Elgar Publishing, 2012, 544 p. ISBN: 9780857938428

DOSTÁL, Ondrej. Koronavírus: smerácky biznis na rozlúčku? Denník N, 16 March 2020. [online] Available at: https://dennikn.sk/1803703/koronavirus-smeracky-biznis-narozlucku/ Accessed: 10.12.2020

EUROPEAN PARLIAMENT. Value for money: EU programme funding in the field of democracy and rule of law - European Union. 2017. [online] doi:10.2861/14536, ISBN: 978-92-846-0377-0

GLENDINNING, R. The Concept of Value for Money. International Journal of Public Sector Management, 1988, vol. 1, no. 1, pp. 42-50, ISSN: 095-3558

HORUBSKI, Krzysztof. Public Contracts by Negotiated Procedure in Cases of Urgency - A New interpretation of the Legal Basis in Light of Experiences with Organization of the 2012 European Football Championships - Wroclaw Review of Law, Administration \& Economics, 2014, vol. 3, no. 1, pp. 105-118, DOI: https://doi.org/10.2478/ wrlae-2013-0046 ISSN: 2084-1264. [online] Available at: https://content.sciendo. com/configurable/contentpage/journals $\$ 002$ fwrlae $\$ 002 \mathrm{f} 3 \$ 002 \mathrm{f} 1 \$ 002$ farticle-p 104 . xml Accessed: 10.12.2020

KRÜGER, Kai. Urgent Needs - Derogatory Procurement Law Scenarios: Reflections over Ius Necessitatis in the Area of Public Contracting - A propos the EC Directive 2007/66, Amending Directive 89/655/EC on Remedies in Public Contracting. $3^{\text {rd }}$ International Public Procurement Conference Proceedings - Enhancing Best Practices in Public Procurement, 2008, pp. 165-190. [online] Available at: http://www.ippa.org/IPPC3/Proceedings/Chaper\%2013.pdf Accessed: 10.12.2020

LOZOVSKY, Ilya. In Europe's Scramble to Buy COVID-19 Supplies, Anti-Corruption Measures Fall Away. 21 April 2020. OCCRP. [online] Available at: https://www.occrp. $\mathrm{org} /$ en/coronavirus/in-europes-scramble-to-buy-COVID-19-supplies-anti-corruption-measures-fall-away Accessed: 6.12.2020

NAČIŠČIONIS, Jānis, TUMALAVIČIUS, Vladas, SKRASTINA, Una, RADZEVIČS, Juris, PRAKAPIENE, Daila. Issues of Public Security: Legal Consequences of Determining Unforseeable Extraordinary Events. Journal of Security and Sustain- 
ability Issues, 2020, vol.9, no.3 pp. 1117-1127, DOI: 10.9770/jssi.2020.9.3(34), ISSN: 2020-7025. [online] Available at: https://jssidoi.org/jssi/uploads/papers/36/ Naciscionis_Issues_of_Public_Security_Legal_Consequences_of_Determining Unforeseeable_Extraordinary_Events.pdf Accessed: 10.12.2020

SANCHEZ-GRAELLS, Albert. European Commission's Guidance on Extreme Emergency Procurement and Covid-19 - Some Thoughts and a Word on the Dyson Contract. 2020. [online] Available at: https://www.howtocrackanut.com/blog/2020/4/1/ european-commissions-guidance-on-extreme-emergency-procurement-and-covid19-some-thoughts Accessed: 10.12.2020

STEINICKE, Michael, VESTERDORF, Peter L. EU Public Procurement Law, Brussels Commentary - Baden-Baden : NOMOS, C. H. BECK, HART, 1.st edition, 2018, pp. 1448, ISBN: 978-3-8487-0120-9

\section{Legal documents, case-law}

Agreement on Government Procurement. Revised text (2012).

Directive 2014/24/EU of the European Parliament and of the Council of 26 February 2014 on public procurement and repealing Directive 2004/18/EC, (OJ L 94, 28. 3. 2014, pp 65-242)

Directive 2014/25/EU of the European Parliament and of the Council of 26 February 2014 on procurement by entities operating in the water, energy, transport and postal services sectors and repealing Directive 2004/17/EC (OJ L 94, 28. 3. 2014, pp. 243-374)

Guidance from the European Commission on using the public procurement framework in the emergency situation related to the COVID-19 crisis (OJ C 108I, 1. 4. 2020, p. $1-5)$

Judgement of the Court of 4 June 2009 in case Commission of the European Communities v Hellenic Republic, C-250/07, ECLI:EU:C:2009:338

Judgement of the Court of 2 June 2005 in case Commission of the European Communities v Hellenic Republic, C-394/02, ECLI:EU:C:2005:336

Judgement of the Court of 10 March 1987 in case Commission of the European Communities v Italian Republic, 199/85, ECLI:EU:C:1987:115

Judgement of the Court of 14 September 2004 in case Commission of the European Communities v Italian Republic, C-385/02, ECLI:EU:C:2004:522

Judgement of the Court of 11 September 2014 in case Ministero dell'Interno v Fastweb SpA, C-19/13, ECLI:EU:C:2014:2194

Judgement of the Court of 22 April 2010 in case European Commission v Kingdom of Spain, C-423/07, ECLI:EU:C:2010:211

Judgement of the Court of 2 August 1993 in case Commission of the European Communities v Italian Republic, ECLI:EU:C:1993:344

Judgement of the Court of 18 March 1992 in case Commission of the European Communities v Kingdom of Spain, C-24/91, ECLI:EU:C:1992:134

Judgement of the Court of 27 October 2005 in case Commission of the European Communities v Italian Republic, C-525/03, ECLI:EU:C:2005:648

Opinion of Advocate General Jacobs delivered on 2 June 2005 in case C-525/03, Commission of the European Communities v Italian Republic, ECLI:EU:C:2005:343

Judgement of the Court of 28 March 1996 in case Commission of the European Communities v Federal Republic of Germany, C-318/94, ECLI:EU:C:1996:149 